\title{
Large-scale slumping deduced from structural and sedimentary features in the Lower Palaeozoic Anglo-Brabant fold belt, Belgium
}

\author{
T. N. DEBACKER ${ }^{1}$, M. SINTUBIN ${ }^{2} \&$ J. VERNIERS ${ }^{3}$ \\ ${ }^{1}$ Vakgroep Geologie en Bodemkunde, Universiteit Gent, Krijgslaan 281, S8, 9000 Gent, Belgium \\ (e-mail: timothy.debacker@rug.ac.be) \\ ${ }^{2}$ Structurele Geologie en Tektoniek, Katholieke Universiteit Leuven, Redingenstraat 16, 1000 Leuven, Belgium \\ (e-mail: manuel.sintubin@geo.kuleuven.ac.be) \\ ${ }^{3}$ Laboratorium voor Paleontologie, Universiteit Gent, Krijgslaan 281, S8, 9000 Gent, Belgium \\ (e-mail: jacques.verniers@rug.ac.be)
}

\begin{abstract}
Distinguishing slump folds from tectonic folds in poorly exposed areas can be difficult, especially when the scale of the slump folds exceeds outcrop scale. In the southeastern part of the single-phase deformed, Lower Palaeozoic Anglo-Brabant fold belt a comparison of cleavage/fold relationships and stratigraphic polarity shows that a $200 \mathrm{~m}$ thick interval of middle Caradoc fine-grained turbidites in the core of a large synform was overturned prior to tectonic deformation. This overturning is attributed to large-scale slumping, which was most likely a result of middle Caradoc seismic activity.

The exposed portion of the large slump sheet contains only a few small slump folds and intraformational breccias, making up less than $5 \%$ of the exposed thickness. If the beds were not overturned, large-scale slumping would never be suspected and the small slump folds would probably be interpreted as localized features in an overall 'stable' sedimentary pile. This may explain why so few ancient large-scale slides and slumps have been reported: the small amount of internal deformation makes them very difficult to recognize, especially when dealing with poorly exposed areas. As such, large ancient slides and slumps may be more common than suggested by the geological literature.
\end{abstract}

Keywords: Anglo-Brabant fold belt, Caradoc, slump folds.

The criteria used in outcrop to distinguish tectonic folds from slump folds generally consist of meticulously characterizing their geometric differences (see Elliott \& Williams 1988). One of the most used criteria is an intrafolial, isolated position of the folds between relatively undeformed sediments (Jones 1939; Kuenen 1949; Helwig 1970; Corbett 1973; Woodcock 1976; Rupke 1976; Potter \& Pettijohn 1977). However, as pointed out by Williams et al. (1969), this arrangement can also arise with intrafolial tectonic folds (Maltman 1994). Often cited is the scattered orientation of slump fold axes in comparison with tectonic fold hinge lines (Jones 1939; Kuenen 1949; Rupke 1976; Potter \& Pettijohn 1977). In certain areas, however, tectonic folds are aligned with slump folds (e.g. Helwig 1970). Furthermore, in areas with strong or poly-phase tectonic deformation (cf. Blewett 1991; Debacker 1999), a large variation in fold hinge lines may occur (e.g. sheath folds, tubular folds), whereas in other areas slump fold axes may reflect a general parallelism throughout the slump sheet (Kelling \& Williams 1966; Woodcock 1976). It has also been argued that slump fold style is very complex and highly irregular as compared to tectonic fold style (Jones 1939; Kuenen 1949; Corbett 1973; Potter \& Pettijohn 1977). Although the irregular shape holds for many slump features, Woodcock (1976) showed that in several cases the range in styles of slump folds closely matches that of tectonic folds. Consequently, in poorly exposed areas where tectonic movements have taken place, distinguishing slump structures from tectonic structures can be very difficult. This difficulty increases when the sizes of slump folds exceed the outcrop size.

An alternative approach to the problem, however, is to use small-scale structural features to distinguish slump folds
(Elliott \& Williams 1988; Maltman 1994). These features include veins, fold-related fractures, cleavage and cleavage/ bedding intersections. Furthermore, since slumps are a form of slides with rotational deformation (Woodcock 1979a), a meticulous comparison of tectonic polarity, based on cleavage-fold relationships, and stratigraphic polarity, based on sedimentological features, can be used to distinguish slump folds. Although the applicability of this approach also has its restrictions (e.g. Helwig 1970; cf. Elliott \& Williams 1988; Blewett 1991; Maltman 1994), the main advantage is that it is particularly useful in single-phase tectonically deformed, poorly exposed areas, even when slump folds are several orders of magnitude larger than the outcrop size.

This work utilizes cleavage/fold relationships in order to distinguish tectonic deformation from soft-sediment deformation in the Lower Palaeozoic Brabant Massif. In this particular case, the combination of structural and sedimentological observations can be used to outline a large-scale slump. Combined with palaeocurrent data and other sedimentological observations, this slump is used to put forward a probable basin geometry of the southern part of the Anglo-Brabant fold belt during the Late Ordovician, to narrow-down the possible directions of slumping and to deduce the probable cause of slumping.

\section{Geological setting}

The study area is situated on the southern rim of the Lower Palaeozoic Brabant Massif (Fig. 1). The Brabant Massif forms the southeastern part of the Anglo-Brabant fold belt, one of 


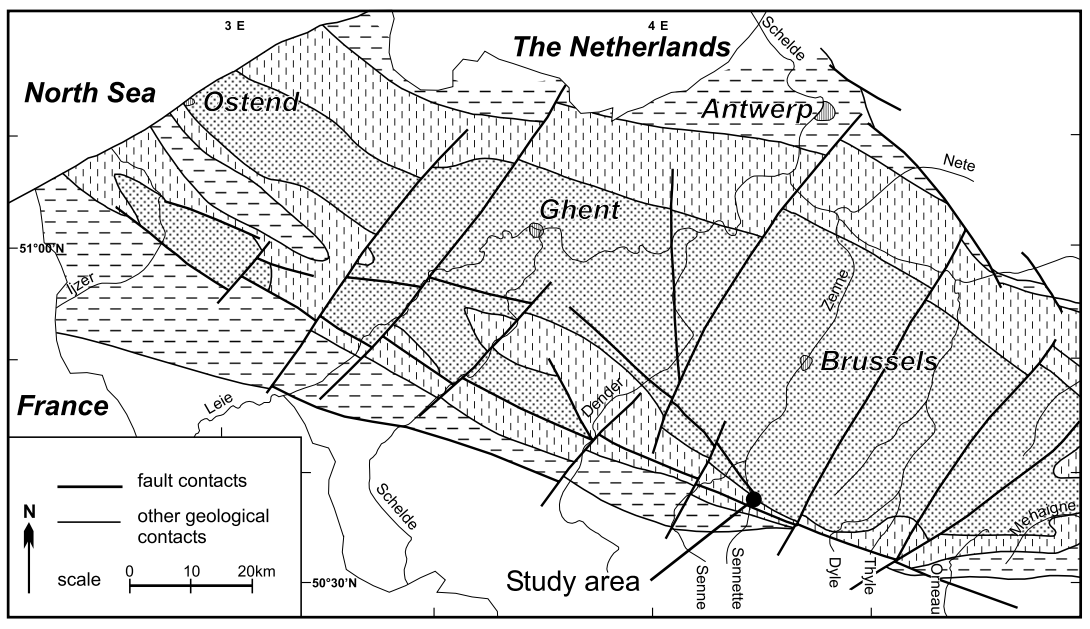

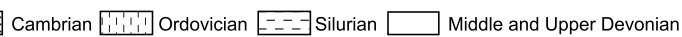

Fig. 1. Geological subcrop map of the Lower Palaeozoic Brabant Massif (after De Vos et al. 1993) with location of the study area. the fold belts resulting from a post-docking plate convergence of eastern Avalonia and Baltica (Sintubin 1999; cf. Van Grootel et al. 1997). The Lower Palaeozoic deposits in the Brabant Massif mainly consist of fine-grained deposits, dominantly turbidites, with some volcanic intercalations and plutonic bodies of Ashgill age (De Vos et al. 1993). Foreland basin development started from the early Silurian onwards (Van Grootel et al. 1997). So far there is only evidence for one single deformation phase, deforming the Lower Palaeozoic rocks into a series of south-verging hectometre to kilometrescale stepfolds with a cogenetic north-dipping cleavage (Van Grootel et al. 1997; Sintubin 1999). As evidenced by the angular unconformity between deformed, epizonal, lower Ludlow (upper Silurian), fine-grained turbidite deposits and overlying, subhorizontal, undeformed Givetian deposits, deformation took place between the Early and early Mid-Devonian (Van Grootel et al. 1997).

The Brabant Massif is poorly exposed. Only along the southern rim of the massif do tributaries of the Schelde and Maas rivers cut through the overlying Cretaceous, Tertiary and Quaternary cover, enabling a direct study of the deformed Lower Palaeozoic rocks. Along the Brussels-Charleroi canal in the Sennette valley $23 \mathrm{~km}$ south of Brussels, a $500 \mathrm{~m}$ long nearly continuously exposed section in the footwall of the Asquempont fault contains an asymmetric hectometre-scale, south-verging synform in fine-grained Upper Ordovician sediments. Legrand (1967) was the first to notice the overturned beds within this synform. Although this overturning was rejected by Martin \& Rickards (1979), both Legros (1991) and Servais (1991) confirmed the reverse stratigraphic polarity of the turbidites in the synform core. However, the presence of these overturned beds has never been properly explained.

\section{Lithology, biostratigraphic age and stratigraphic polarity}

From NE to SW four well-exposed outcrops are present (Fig. 2). A section along the canal, perpendicular to the structural trend, is shown in Fig. 3. The litho- and biostratigraphy used is based on Van Grootel et al. (1998) and Verniers et al. (in press).

Outcrop A contains homogeneous dark grey to bluish grey mudstone to fine-grained siltstone of the lower Llanvirn Rigenée Formation. Only in a few cut samples do vague changes in grain size or alignments of pyrite reveal steeply dipping bedding. Determining the stratigraphic polarity (i.e. way-up) was not possible. However, $200 \mathrm{~m}$ north of this outcrop, sedimentological features (cross-bedding, graded bedding, sharp contacts) in steeply south-dipping beds of the upper Arenig Tribotte Formation, indicate a normal stratigraphic polarity, younging towards the south. In a zone of $12 \mathrm{~m}$, between outcrops A and B, volcanic intercalations occur, the thickest bed being $4 \mathrm{~m}$ wide. These tuffs (Corin 1963) are interstratified with the sediments of outcrops B and B'.

Outcrops B and B', respectively situated at the eastern and western side of the canal, expose the synform core. The rocks consist of distinct alternations of light grey fine-grained sandstones, medium grey siltstones and dark grey mudstones interpreted as fine-grained turbidite deposits, dominantly Tcde-Bouma sequences (Bouma 1962, Servais 1991), of the middle Caradoc Ittre Formation (Fig. 4a). The turbidite sequences are generally $5-15 \mathrm{~cm}$ thick, with the sandy to silty c-intervals normally comprising $20-35 \%$ of the sequence thickness (Servais 1991). Towards higher levels, in the southern part of outcrops B and B', turbidites appear to become finer grained, with fewer c-intervals. Locally, small-scale softsediment deformation is evidenced by load-casts, convolutions and small ball-and-pillow structures. Throughout outcrops B and B' sedimentary features, such as graded bedding, crossbedding, truncations of older beds by younger beds and turbidite sequences, indicate a reverse stratigraphic polarity. In the steep northern limb of the synform, the beds young towards the north, towards the older core of the Brabant Massif. In the subhorizontal southern limb the beds young downwards.

Outcrop C contains moderately north-dipping beds of a centimetric alternation of light to medium grey fine-grained sandstones to siltstones and dark grey to black mudstone, which are attributed to the middle Caradoc Bornival Formation by Verniers et al. (in press). It should be emphasized, however, that both lithologically and sedimentologically, these beds differ from those in the type section of the Bornival Formation more to the south, where they consist of less distinct alternations of dark grey siltstone and dark grey to black mudstone (Van Grootel et al. 1998; Verniers et al. in press). Personal observations and those of others (Herbosch unpublished data) indicate that the beds in outcrop $\mathrm{C}$ appear turbiditic, with individual Tcde-sequences of $1-4 \mathrm{~cm}$. In 


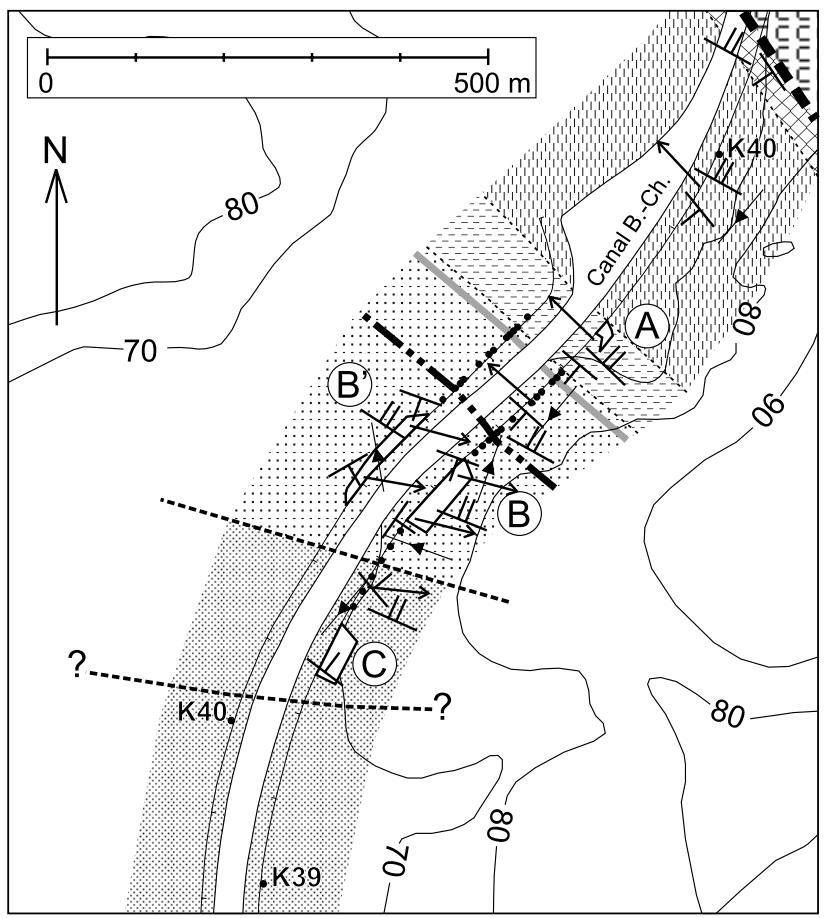

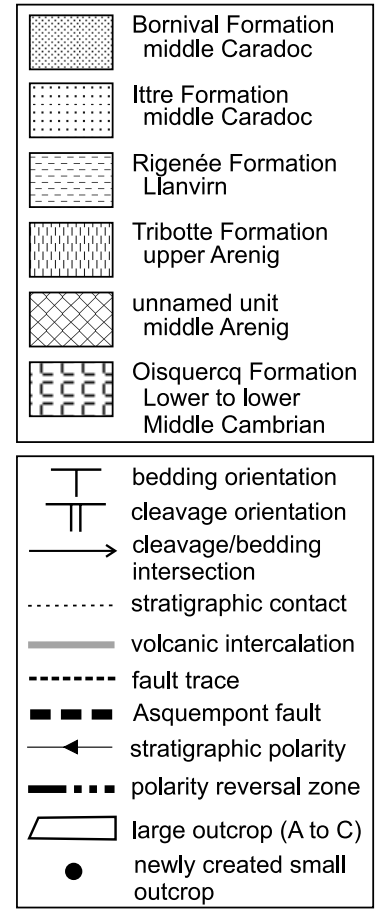

Fig. 2. Simplified topographic map of the Asquempont section, along the Brussels-Charleroi canal in the footwall of the Asquempont fault, showing the studied outcrops, the distribution of the stratigraphic units, the stratigraphic polarity and structural data. Contours in metres. K39 and K40 are kilometre posts along the east and west side of the canal.

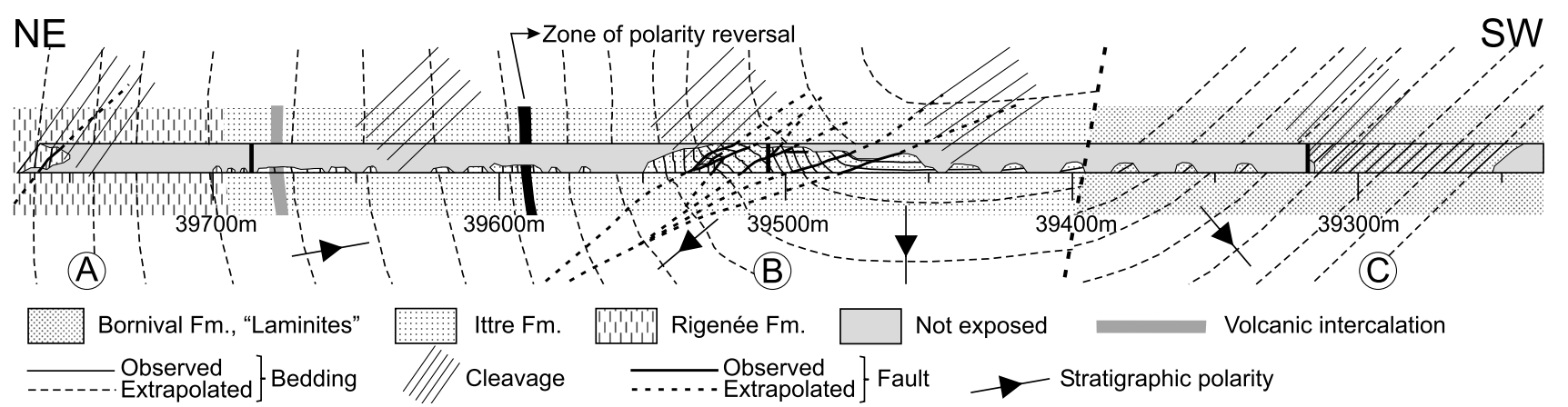

Fig. 3. Section along the east side of the Brussels-Charleroi canal, showing a large synformal south-verging fold with overturned bedding. See Fig. 2 for location of outcrops A-C.

contrast, a turbiditic nature cannot be inferred for the classical Bornival Formation. Furthermore, the resolution of the biostratigraphy is not high enough to differentiate the beds of outcrop $\mathrm{C}$ from either the Ittre Formation or the Bornival Formation. To avoid confusion, these beds will, for the current purpose, be referred to as the 'laminites', an informal field term.

A distinct feature of the beds in outcrop $\mathrm{C}$ is the pronounced soft-sediment deformation, always restricted to several beds, in zones several centimetres wide. In cross-section, the dark-grey clayey beds commonly contain numerous lenticular to oval silt to fine sand bodies, with a diameter of a few millimetres to $1 \mathrm{~cm}$, elongated subparallel to bedding (Fig. 4b, c). Also several of the thicker silty beds (up to $3 \mathrm{~cm}$ thick) show a similar internal disruption (Fig. 4c). Although resembling small ball-and-pillow structures (see Potter \& Pettijohn 1977; Pettijohn et al. 1987), three-dimensional observations show that in several cases these apparently lenticular structures are sectional views of bedding-parallel tubular systems, interpreted as bioturbation. Apart from these, many small-scale, nonbiogenic synsedimentary deformation structures occur. These include load-casts, ball-and-pillow structures, convolutions, contortions, truncations and intraformational folds (Fig. 4d). Although biogenic and non-biogenic structures are present in several zones throughout the outcrop, in several cases next to each other, most of the non-biogenic structures are found at the southern end of the outcrop (39 280-39 $250 \mathrm{~m}$ ). Where the soft-sediment deformation in outcrop $\mathrm{C}$ was less pronounced or absent, a reverse stratigraphic polarity could be determined.

\section{Structural data}

Orientation data of structural elements are shown in Table 1 and Fig. 6. The area around outcrop A contains the northern fold limb, the area around outcrops B and B' the synform hinge zone and the area around outcrop $C$ the southern limb. In order to get enough data from each area, several small new exposures were made by clearing the undergrowth and debris (Fig. 2).

Outcrops B and B', containing the synform hinge zone, essentially show the same overall structure: a large open, asymmetric, subhorizontal to gently ESE-plunging synform with a gently to moderately NE-dipping axial surface. The 


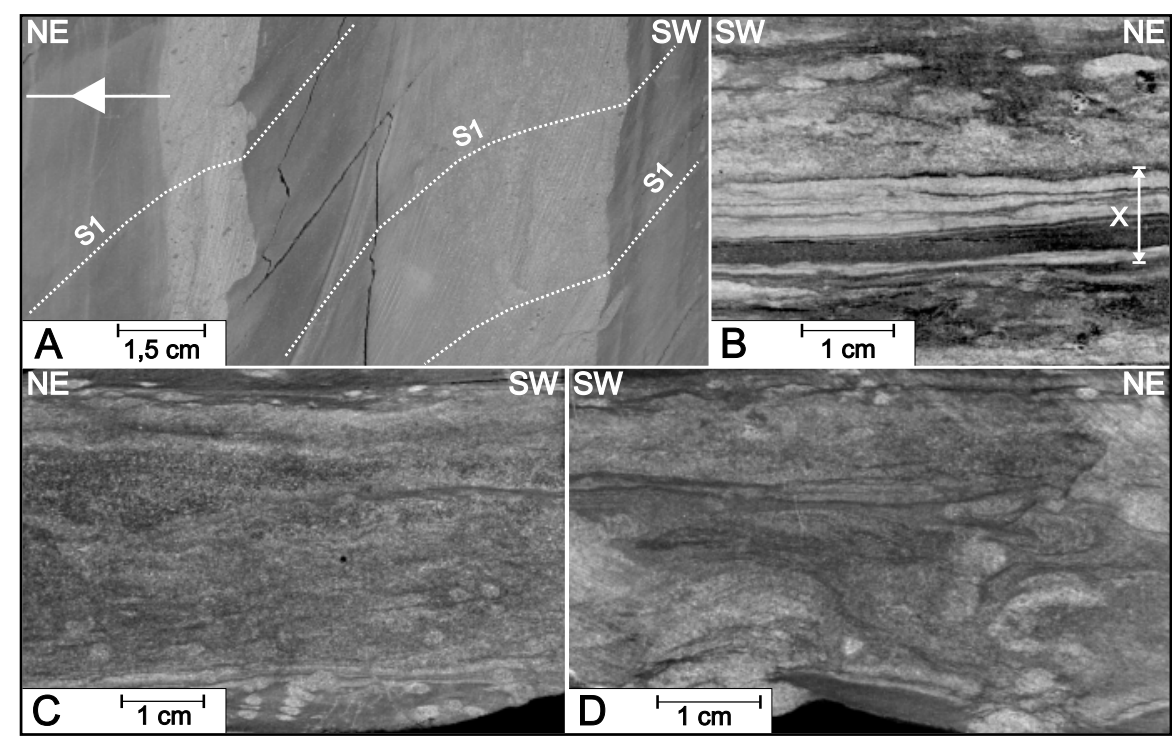

Fig. 4. Small-scale sedimentological observations in the overturned beds of outcrops B and C. (a) Relatively undisturbed turbidites of the Ittre Formation in outcrop B, younging towards the NE (shown by arrow) as indicated by graded bedding, small load casts, sharp contacts and turbidite sequences (Tcde). Also the cleavage refraction pattern (S1) can be used to determine the younging direction (39549,5 $\mathrm{m}$ ). (b)-(d) Soft-sediment deformation of biogenic (b, c) and non-biogenic (d) origin in outcrop C. (b) Relatively undisturbed beds (X) with a reverse stratigraphic polarity (younging towards below) between partly to completely disrupted beds (39 $247 \mathrm{~m}$ ). (c) Silt to fine sandstone showing internal disruption of layers into lenticular bodies, best visible along the edges of the bed (39 $286 \mathrm{~m})$. (d) Silty bed with internal remobilization of fine silt to fine sand forming irregular bodies of coarser grains (pale-coloured) between zones of finer material (dark coloured); note the small recumbent folds (39257 m).

hinge zone of the large south-verging synformal structure contains several small, open, parasitic folds with a southverging asymmetry and a stepfold-like geometry (Fig. 5). The orientation of the fold hinge lines of individual small folds is subparallel to the fold hinge line of the overall structure.

The section is cut by a pervasive, moderately NE-dipping, cleavage. This cleavage is axial planar to the small folds in the hinge zone of the synform and approximately axial planar to the large synform. In accordance with the generally finegrained lithology, the cleavage shows divergent cleavage fanning across the small folds (Fig. 5). A large-scale divergent cleavage fan across outcrops B, B' and A can also be inferred from changes in the mean cleavage orientation (Fig. 3). In outcrop $\mathrm{C}$, situated in the southern, normal limb of the synform, cleavage dips only a few degrees steeper than bedding. Because of the small angle between bedding and cleavage, cleavage could not be measured in this outcrop. Changes in cleavage dip allow the construction of a virtual cleavage/cleavage intersection (B-axis of cleavage planes, axis of cleavage fan). The term 'virtual' is used because, dealing with only one tectonic cleavage, true cleavage/cleavage intersections are not present in outcrop (see Debacker et al. 1999). The overall virtual cleavage/cleavage intersection is subparallel to the overall fold hinge line. This also accounts for the cleavage/bedding intersections.

The orientation of some of the structural elements changes along the section. Going from south to north, the trend of bedding and cleavage/bedding intersections abruptly changes from WNW-ESE to NW-SE around $39600 \mathrm{~m}$ (Fig. 6). The east to SE plunge of fold hinge lines and intersection lineations is not common in this part of the Brabant Massif. Both to the south, in the Silurian of Ronquières (Debacker et al. 1999), and to the north (Fig. 2, Debacker unpublished data) fold hinge lines and cleavage/bedding intersections plunge towards the NW, as is the case in the zone around outcrop A
(39 600-39 $800 \mathrm{~m}$ ). On the other hand, both the strike of the cross-joints, oriented at high angles to the fold hinge lines, and of the cleavage appear to remain fairly constant throughout the section.

Taking into account the somewhat unusual orientation of the folds and the abrupt change in bedding orientation around $39600 \mathrm{~m}$, the above outline of the cleavage/fold relationships throughout the small stepfolds in the synform core suggests that cleavage and folding are cogenetic. Also the fractures are consistent with the folds. As such, all structural data suggest a single-phase tectonic deformation.

\section{Slump folds}

In several places in outcrop $\mathrm{C}$ and between outcrops $\mathrm{C}$ and $\mathrm{B}$, slump folds can be observed. The best examples occur in two newly created exposures in the turbidites of the Ittre Formation between $39420 \mathrm{~m}$ and $39440 \mathrm{~m}$ (Fig. 7). Each one contains a subhorizontal, open antiform-synform couple in a 1-2 $\mathrm{m}$ wide zone between relatively undisturbed beds. Several features, such as the localized occurrence of these folds between relatively undeformed planar surfaces, the truncations of the bedding and the difference in orientation of these folds with regard to the tectonic folds may indicate a slump origin. However, the most convincing evidence for a pre-tectonic origin of these folds lies in the cleavage/fold relationships. Because of the difference in asymmetry between the tectonic folds and the slump folds, the tectonic fold-related cleavage cuts across the small slump folds at a high angle to their axial surfaces, commonly leading to very strange cleavage refraction patterns in their hinge zones (Fig. 7). Apart from the fold asymmetry, the fold style of the slump folds is not very different from the style of the tectonic folds (see Woodcock 1976) and also their trend approximates that of the tectonic folds (Fig. 6, see Helwig 1970). 
Table 1. Orientations of bedding, cleavage, cleavagelbedding intersections and transverse fractures along the Brussels-Charleroi canal, between 39200 and $39800 \mathrm{~m}$

\begin{tabular}{|c|c|c|c|}
\hline Bedding & Cleavage & Cleavage-bedding intersection & Fractures, cross-joints \\
\hline $\begin{array}{l}\text { Outcrop } A, 39800-39600 \mathrm{~m} \\
N=40 \\
\text { B axis: } 08 / 310 \\
\text { Mean: } 132 / 78 \mathrm{SW}\end{array}$ & $\begin{array}{c}\quad N=57 \\
\text { B axis: } 20 / 325 \\
\text { Mean: } 306 / 48 N E\end{array}$ & $\begin{array}{c}\qquad \begin{array}{c}N=12 \\
\text { Mean: } 16 / 311 \\
\text { Plunge dir.: } 311 \pm 005^{\circ}\end{array}\end{array}$ & $\begin{array}{c}\quad N=16 \\
\text { Mean: } 227 / 84 \mathrm{NW} \\
\text { Strike: } 227 \pm 011^{\circ}\end{array}$ \\
\hline 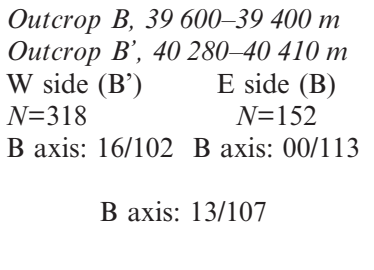 & $\begin{array}{cc}\text { W side (B') } & \text { E side }(\mathrm{B}) \\
N=86 & N=111 \\
\text { B axis: } 18 / 096 & \text { B axis: 00/112 } \\
\text { Mean: 303/36NE } & \text { Mean: 292/39NE } \\
\text { B axis: } 11 / 101 \\
\text { Mean: } 297 / 38 N E\end{array}$ & $\begin{array}{cc}\text { W side (B') } & \text { E side (B) } \\
N=61 & N=40 \\
\text { Mean: } 17 / 102 & \text { Mean: } 01 / 107 \\
\text { Plunge dir.: } 102 \pm 007^{\circ} & \text { Plungedir.: } 107 \pm 011^{\circ} \\
\text { Mean: } 11 / 104 & \\
\text { Plunge dir.: } 104 \pm 009^{\circ}\end{array}$ & $\begin{array}{cc}\text { W side (B') } & \text { E side }(\mathrm{B}) \\
& N=88 \\
\text { No data } & \text { Mean: } 217 / 82 \mathrm{NW} \\
& \text { Strike: } 217 \pm 018^{\circ} \\
& \text { See B }\end{array}$ \\
\hline $\begin{array}{l}\text { Outcrop } C, 39400-39200 \mathrm{~m} \\
N=27 \\
\text { B axis: } 30 / 338(?) \\
\text { Mean: } 300 / 44 \mathrm{NE}\end{array}$ & No data & No data & $\begin{array}{c}\quad N=63 \\
\text { Mean: } 209 / 88 \mathrm{~W} \\
\text { Strike: } 209 \pm 019^{\circ}\end{array}$ \\
\hline $\begin{array}{l}\text { Summary } 39200-39800 \mathrm{~m} \\
N=537 \\
\text { B axis: } 13 / 111\end{array}$ & $\begin{array}{c}\quad N=254 \\
\text { B axis: } 06 / 111 \\
\text { Mean: } 299 / 40 \mathrm{NE}\end{array}$ & $\begin{array}{c}N=113 \\
\text { Mean: } 08 / 106 \\
\text { Plunge dir.: } 106 \pm 012^{\circ}\end{array}$ & $\begin{array}{c}\quad N=167 \\
\text { Mean: } 215 / 85 N W \\
\text { Strike: } 215 \pm 018^{\circ}\end{array}$ \\
\hline $\begin{array}{l}8 \text { Small tectonic folds in the } \\
N=131 \\
\text { B axis: } 15 / 103\end{array}$ & $\begin{array}{l}\text { nge zone of the synform, outcrop B', } \\
\qquad N=23 \\
\text { B axis: } 18 / 097 \\
\text { Mean: } 293 / 50 \mathrm{NE}\end{array}$ & $\begin{array}{r}\text { West side canal, } 40340-40370 \mathrm{~m} \\
N=32 \\
\text { Mean: } 18 / 102 \\
\text { Plunge dir.: } 102 \pm 007^{\circ}\end{array}$ & No data \\
\hline
\end{tabular}

Extreme values of plunge direction in the hinge zone are 21/095 $(n=12$, antiform at $40344 \mathrm{~m})$ and 14/110 ( $n=13$, antiform at $40348 \mathrm{~m})$, extreme plunge values $01 / 106(n=30$, antiform at $40362 \mathrm{~m})$ and 22/102 $(n=12$, antiform at $40345 \mathrm{~m})$.

The orientation of planar elements (bedding, cleavage, fractures) is given as strike/dip, with indication of dip direction (e.g. 306/48 NE), the orientation of linear elements (cleavage/bedding intersections, B axes) is given as plunge/plunge direction (e.g. 16/311). In the case of bedding, the $\mathrm{B}$ axis represents the fold hinge line, in the case of cleavage planes, the B axis represents the virtual cleavage/cleavage intersection. See Fig. 2 for location of outcrops A-C.

\section{Comparison of structural and sedimentological observations}

As shown above, the cleavage/fold relationships suggest a cogenetic relationship between tectonic folding and cleavage development. Because of this cogenetic nature, cleavage/fold relationships can be used to determine the tectonic polarity: where cleavage dips steeper than bedding tectonic polarity is normal, whereas where bedding dips steeper than cleavage tectonic polarity is reverse. In the example of an asymmetric, moderately inclined, close to tight synform, formed during a single-phase, south-verging deformation, the northern limb will have a reverse tectonic polarity, whereas the southern limb will have a normal tectonic polarity. Starting off with a normal stratigraphic polarity, the northern, overturned, limb will young downwards, the southern limb upwards. Similarly, in the less asymmetric, open synform along the Asquempont section, we would expect the southern limb, with a normal tectonic polarity, to young upwards and the northern, tectonically reverse, limb to young towards the south. In contrast, however, the opposite is observed: in the tectonically normal limb the beds young downward, whereas in the tectonically reverse limb the beds young towards the north.
This contradiction implies that bedding was overturned before the observed single-phase tectonic deformation took place.

\section{Discussion}

There are two possible causes for this overturning. One is a tectonic deformation phase, inverting the bedding prior to the observed Early to early Mid-Devonian folding and cleavage development. This tectonic deformation could then have deformed the beds by means of large-scale recumbent folding, probably accompanied by thrusting. During such a tectonic deformation one would expect the development of a tectonic fabric. Apart from a microscopic bedding-parallel compaction fabric (Maltman 1981), which can also be observed in other places inside the Brabant Massif (Debacker et al. 1999), and the cleavage fabric related to the observed tectonic folds, there are no traces of an older tectonic fabric. Also the restricted stratigraphic occurrence of this overturning - to the authors' knowledge the middle Caradoc in the Asquempont section is the only place - argues against a tectonic origin.

The other plausible explanation for the inverted bedding, without necessitating an unknown deformation phase, is by 


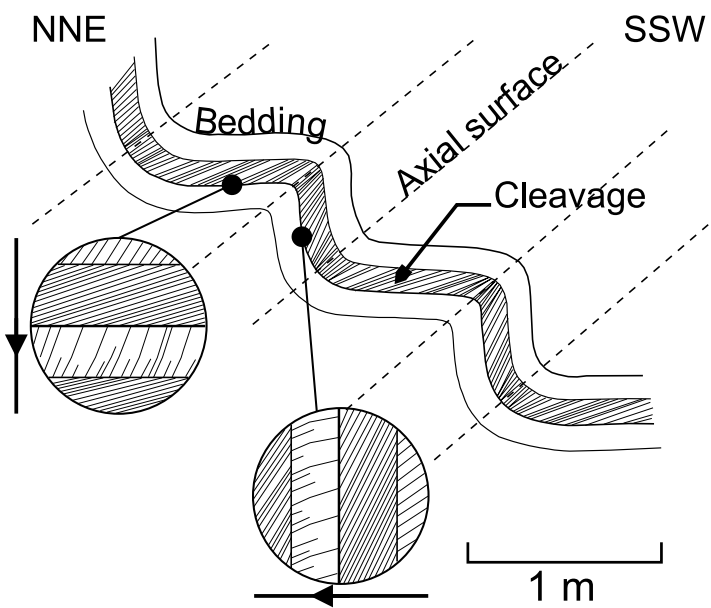

Fig. 5. Cleavage-fold relationships in small asymmetric stepfolds in the fold hinge of the large synformal stepfold. The fold sequence shown is taken from outcrop B', between 40340 and $40350 \mathrm{~m}$.

large-scale slumping. Slump folds and slump-related features occur in several places throughout the section. These include intraformational breccias (outcrop B'), intraformational, truncated folds (outcrop C) and truncated bedding (outcrops B, B', C). The presence of instabilities at the time of, or shortly after, sediment deposition is also indicated by a number of small-scale, soft-sediment deformation structures, the highest concentration of which is found in outcrop C.

In order to test the hypothesis of overturning by slumping, the contact had to be found between the overturned sediments, with a reverse stratigraphic polarity, and the relatively undisturbed underlying sediments with a normal stratigraphic polarity. For this purpose, 25 small new exposures were opened along the canal between outcrops B-B' and A (12 along the west side of the canal, 13 along the east side). For each exposure, stratigraphic polarity was determined in outcrop and checked on oriented cut hand specimens. The revealed contact (Fig. 8, cf. Fig. 2) is not a smooth surface but consists of an irregular zone of truncated and folded discontinuous beds cut by welded faults (cf. Elliott \& Williams 1988). The truncation surfaces and welded faults show no striations. The nature of the deformation and the cleavage/bedding relationships indicate that this deformation took place before cleavage development and lithification.

A fine-grained, $4 \mathrm{~m}$ thick volcanic intercalation in the lower parts of the Ittre Formation, close to the contact between the Ittre Formation and the underlying Rigenée Formation, was used as a marker bed to link both sides of the canal. Bedding measurements and the trend on map of the volcanic intercalation and the polarity reversal zone indicate that the polarity reversal zone is oblique to the overturned bedding (Fig. 2). Furthermore, the change in orientation of the cleavage/ bedding intersections, from ESE-plunging to NW-plunging, occurs around this zone, suggesting that the overturned slumped mass is oblique to the underlying relatively undisturbed beds. Although having the same lithology, sedimentology and biostratigraphic age, the turbidites to the north of the polarity reversal zone cannot be correlated with the overturned turbidites south of the polarity reversal zone. To the north, a rather exceptional $10 \mathrm{~m}$ thick sequence of fine sandy turbidites, with individual Tc intervals of $30 \mathrm{~cm}$ thick, occurs adjacent to the polarity reversal zone. Further north, the turbidites become much finer grained, with turbidite sequences of $5 \mathrm{~cm}$ thick or less (dominantly Tde) around the volcanic marker bed. In contrast, immediately south of the polarity reversal zone, turbidites are fine grained, with sequence thicknesses in the order of $5-10 \mathrm{~cm}$, with few c-intervals, gradually becoming thicker towards $39530 \mathrm{~m}$, where Tcde sequences are generally 5-15 cm thick (cf. Servais 1991).

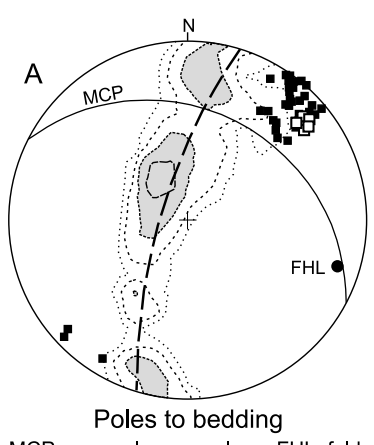

MCP: mean cleavage plane; $F H L$ : fold hinge line

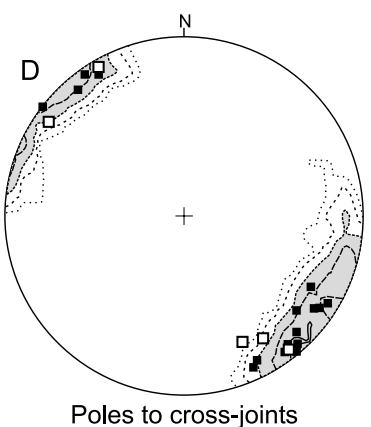

Poles to cross-joints

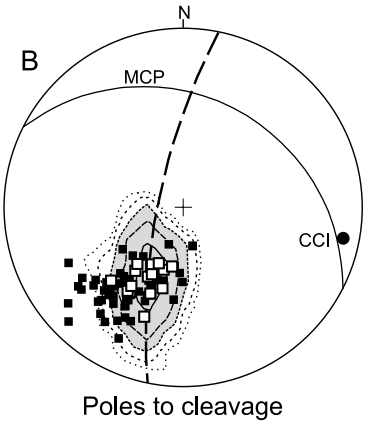

MCP: mean cleavage plane; $\mathrm{CCl}$; virtual cleavage/cleavage intersection

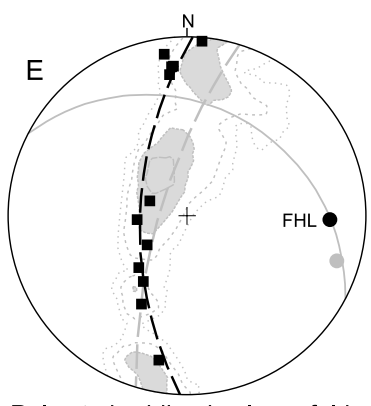

Poles to bedding in slump folds FHL: fold hinge line; grey background: data from plot $A$.

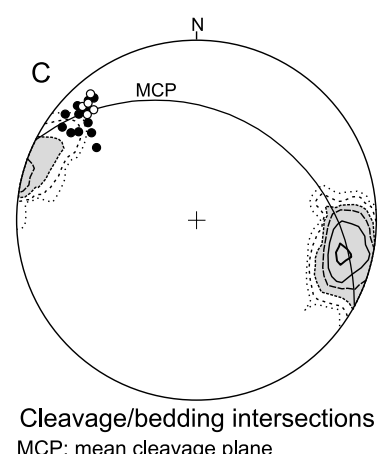

MCP: mean cleavage plane

Contours: contours of poles to planar elements (plot A, B, D, E) or contours of linear elements (plot C) between $39200 \mathrm{~m}$ and $39600 \mathrm{~m}$.

................ $1 \%$ $2 \%$

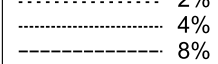

$16 \%$
$-12 \%$

口, : poles to planar elements respectively linear elements from $39600 \mathrm{~m}$ to $39800 \mathrm{~m}$

$\square, \bigcirc$ : poles to planar elements respectively linear elements from $39930 \mathrm{~m}$ to $39950 \mathrm{~m}$

- - - - : best fit girdle

through poles to planar element
Fig. 6. Lower-hemisphere equal-area stereographic projections of poles to bedding (a), poles to cleavage (b), cleavage/bedding intersections (c), poles to transverse fractures (d) and poles to bedding in slump folds (e). In projections (a) to (d) the data from 39200 to $39600 \mathrm{~m}$, contoured, are overlain by data from between 39600 to $39800 \mathrm{~m}$ (black circles and squares) and data from between 39930 to $39950 \mathrm{~m}$ (white circles and squares). For the number of measurements used in the contoured data sets see Table 1. A change in orientation between contoured and overlain data is apparent from the poles to bedding (a) and the cleavage/bedding intersections (c). 


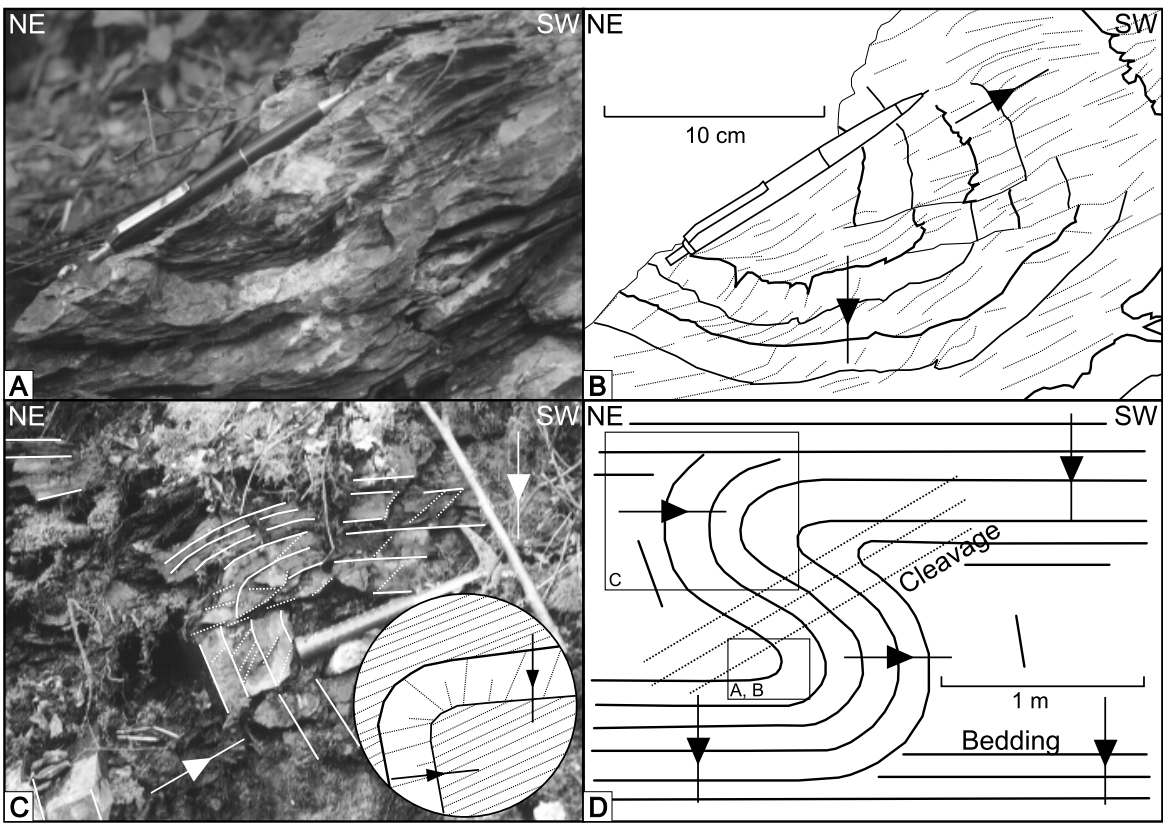

Fig. 7. Pre-cleavage deformation interpreted as slump folding. (a) \& (b) Small asymmetric fold structure in the turbidites of the Ittre Formation, cut by a tectonic NE-dipping cleavage (39 $422 \mathrm{~m}$ ). (c) Asymmetric fold structure cut by cleavage (39437 m). Note the overlying relatively undisturbed bedding (upper left). In both examples cleavage/fold relationships clearly show that folding predates cleavage development. (d) Schematic representation of slump folding between 39420 and $39440 \mathrm{~m}$ : an antiform-synform couple, cut by a NE-dipping cleavage, sandwiched between relatively undisturbed turbidites with a reverse stratigraphic polarity.

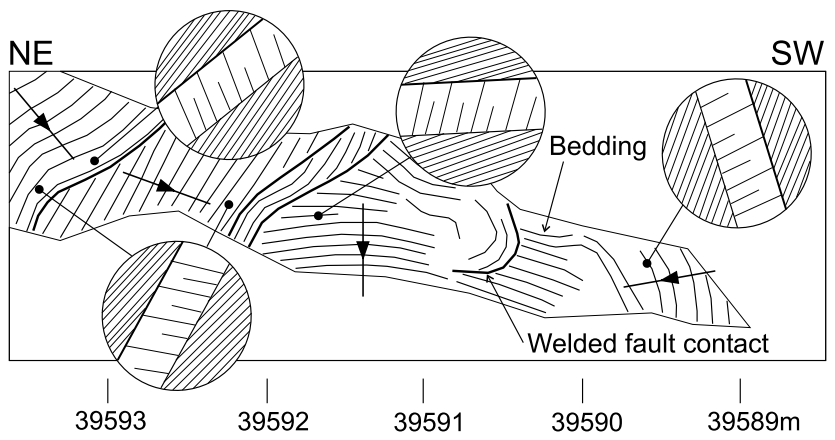

Fig. 8. Polarity reversal zone between overturned (SW) and normal polarity turbidites (NE) in the steep northern limb of the large synform (see Fig. 2 for location). The cleavage/bedding relationships (circular insets) show that the contact and the overturning predate cleavage development. Truncations and fault contacts are welded.

\section{Geometry and thickness of the slump sheet}

The section shown in Fig. 9 is an attempt to unravel the slump sheet geometry. As discussed above, the polarity reversal zone is oblique to the overturned turbidites, pre-dates tectonic deformation and therefore also describes a large synformal fold structure, which, because of the obliquity with bedding, does not display the same curvature as the turbidites in outcrops B and B'. Because slumps are not known to cut significantly into older strata, the slump contact (polarity reversal zone) is drawn roughly parallel to the underlying bedding. Taking into account the stratigraphic polarity and the stratigraphy as proposed by Verniers et al. (in press), we infer overturned turbidites of the Ittre Formation above the monoclinal 'laminites' of outcrop C. Likewise, at a certain depth below outcrop B and B', above the slump contact, we expect the continuation of the 'laminites' of outcrop C. This
NE

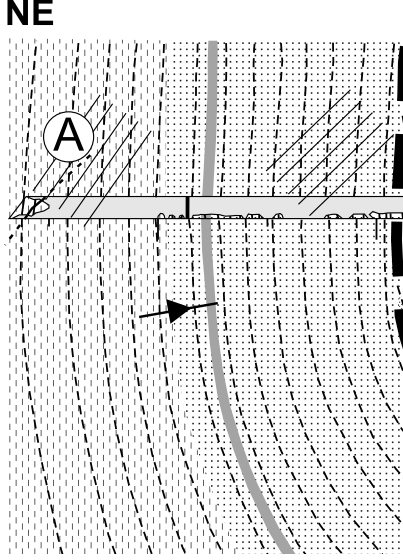

Bornival Fm., "Laminites"

Volcanic intercalation

Stratigraphic polarity $\longrightarrow$ polarity reversal zone

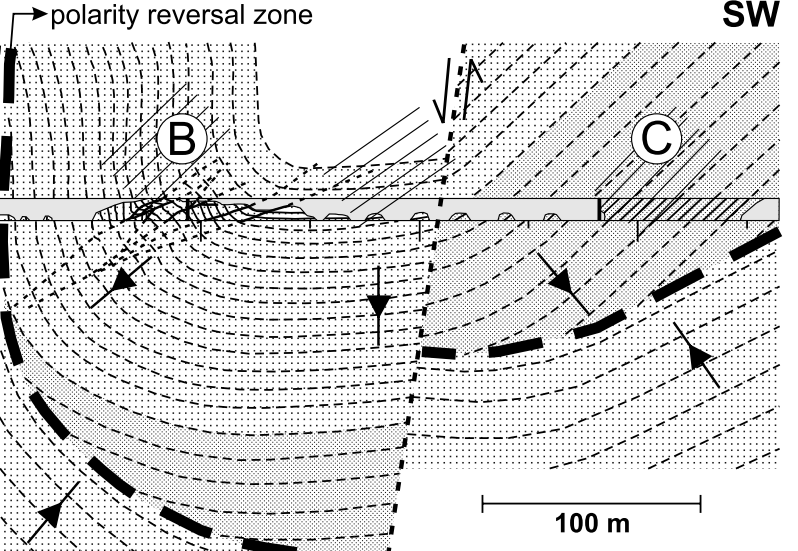

Ittre Fm.
Cleavage
Rigenée Fm.

- 3 Bedding $\square$ Not exposed

....... Fault
Fig. 9. Inferred geometry of the overturned, slumped sequence along the studied section. A combination of the stratigraphic, structural and sedimentological data implies a wedge-shaped geometry. Note that the exact displacement along the fault is unknown. 


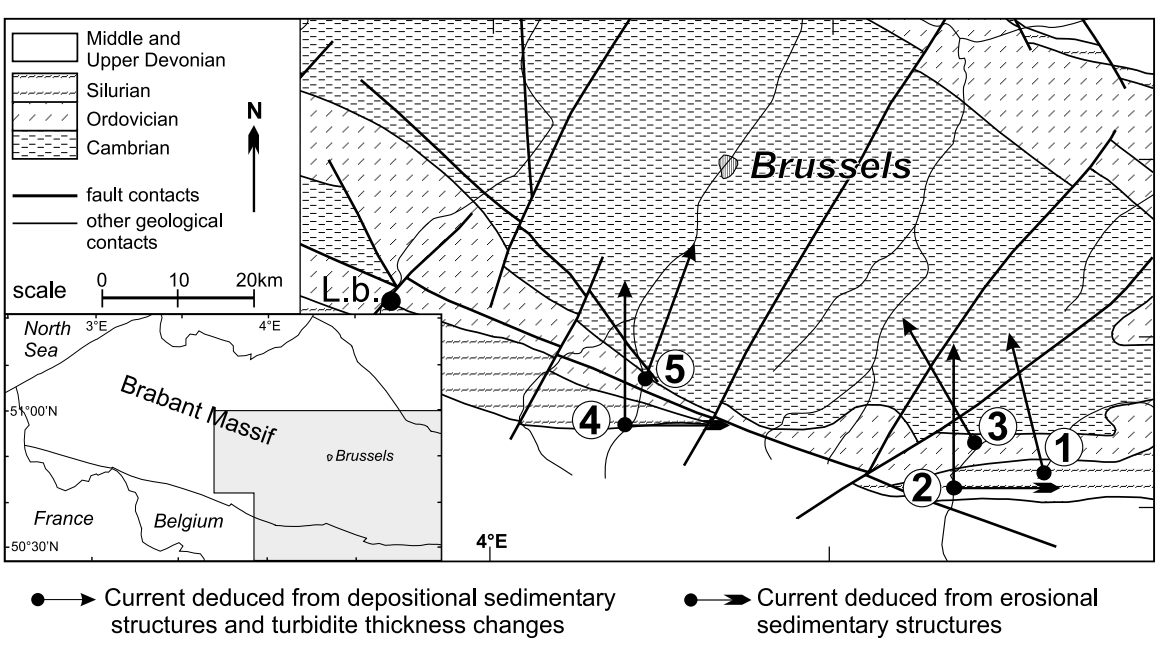

Fig. 10. Subcrop map of the southern rim of the Brabant Massif (after De Vos et al. 1993) showing palaeocurrent directions in turbidite deposits as deduced from primary depositional (ripple marks, cross-bedding) and erosional (flute casts) sedimentary features and turbidite thickness changes. 1, Mehaigne valley, Llandovery and Wenlock (Verniers 1983). 2, Orneau valley, Wenlock (Verniers \& Van Grootel 1991). 3, Orneau valley, middle Caradoc, Ittre Formation (Verniers unpublished data). 4, Sennette valley, Brussels-Charleroi canal, lower Ludlow (Louwye et al. 1992). 5, Sennette valley, Brussels-Charleroi canal, middle Caradoc Ittre Formation, below the slumped mass. L.b., position of the Lessines borehole. necessitates a fault between outcrop $\mathrm{B}$ and $\mathrm{C}$, affecting the overturned turbidites, the 'laminites' and the polarity reversal zone. Indeed a large post-cleavage fault was encountered at $39400 \mathrm{~m}$. It appears that, because of the relative positions of the turbidites and 'laminites', the polarity reversal zone has to be oblique to the overturned bedding, indepently confirming the obliquity seen on the map and deduced from orientation measurements (see Fig. 2). This obliquity implies a wedgeshaped geometry of the overturned, slumped, sedimentary pile.

This wedge shape may offer an explanation for the cleavage/ bedding relationships observed in outcrop $C$ (Figs $3 \&$ 9). The small angle between cleavage and bedding in this outcrop is rather exceptional for the normal limb of an open fold structure. However, considering the scale of the synform structure, the overturned strata will only form a minority of the total thickness $(>1 \mathrm{~km})$ of the beds affected by this synform. The overall geometry of the fold and the orientation of the axial-planar cleavage will be determined mainly by the majority of the beds. Because of the wedge shape, the relatively undisturbed beds in the normal southern limb of the synform, below the contact, may be subhorizontal to gently northdipping, with a moderate angle between bedding and cleavage (as one would expect), whereas above the slump contact the beds are moderately north-dipping, with a very small angle between bedding and cleavage.

The estimated minimum thickness of the overturned slumped mass is in the order of $200 \mathrm{~m}$. Considering its large thickness, a considerable lateral extent may be expected. With the exception of the Lower to lower Middle Cambrian and the lower Tremadoc, slump folds appear to be scarce in the Brabant Massif (Legrand 1968; Giese et al. 1997). However, in the Lessines borehole, situated approximately $30 \mathrm{~km}$ west of the Asquempont section (Fig. 10), a sequence of $85 \mathrm{~m}$ of turbidite deposits of the middle Caradoc Ittre Formation contains numerous slump structures (Herbosch et al. 1991). Although these middle Caradoc turbidites are not recorded as overturned, it is possible that the high concentration of slump folds in this stratigraphic level in the borehole is related to the large overturned mass in the Asquempont section.

\section{Implications for basin geometry and palaeoslopes}

Since Jones' (1939) proposal that during flow slump fold axes will tend to become aligned parallel to one another and to the strike of the palaeoslope, numerous authors have used slump fold orientations to determine the direction and trend of the palaeoslope. Although in the study area the small slump folds appear to have a parallel orientation, with axes even subparallel to the tectonic fold hinge lines, their paucity inhibits the use of any statistical methods (see Jones 1939; Hansen 1965; Woodcock 1979b). Especially in view of reports of slump folds oriented at high angles to the trend of the palaeoslope (Helwig 1970; Lajoie 1972), the determination of the palaeoslope on the basis of only a few small slump folds should be avoided.

The present day pattern of the Upper Ordovician and Silurian of the Brabant Massif, as a part of the Anglo-Brabant fold belt, suggests a NW-SE- to east-west-trending elongate basin (see Verniers 1983; Verniers \& Van Grootel 1991), similar to many turbidite troughs (see Kuenen 1957, 1967; Rupke 1976; Ricci Lucchi 1978). Given this geometry, slumping would be expected to have predominated along the steep northern and southern slopes of the basin (see Kuenen 1967; Pettijohn et al. 1987). The observed east-west-trending slump folds in the Asquempont section seem compatible with this basin geometry.

Several authors have mentioned causal relationships between gravity-driven, down-slope moving slumps and turbidity currents (Gorsline \& Emery 1959; Moore 1961; Kuenen 1967; Potter \& Pettijohn 1977; Kastens 1984; Pettijohn et al. 1987). As such, they could theoretically both be used to estimate the direction of the palaeoslope. In contrast, however, many turbidite basins with a trough-like geometry are characterized by axial flows (Kuenen 1957; Cummins 1957; Kelling 1962; Scott 1966; Klein 1966; Ricci Lucchi 1978).

Published data and personal observations from the Upper Ordovician to upper Silurian along the southern rim of the Brabant Massif (Fig. 10) show that all recorded ripple marks, cross-bedding foresets and lateral changes in number and thickness of turbidite sequences indicate a north-directed current. However, east-west-directed flute-casts in the Silurian (2 and 4 on Fig. 10) point to an eastward current, subparallel to the axis of the Brabant Massif. Several authors have reported similar differences between current directions indicated by different sedimentological features (e.g. Dewey 1962; Kelling 1964; Kuenen 1967; Stow \& Lovell 1979; Kneller et al. 1991; Smith \& Anketell 1992) and a similar discrepancy has also been reported between currents from sedimentary features and 

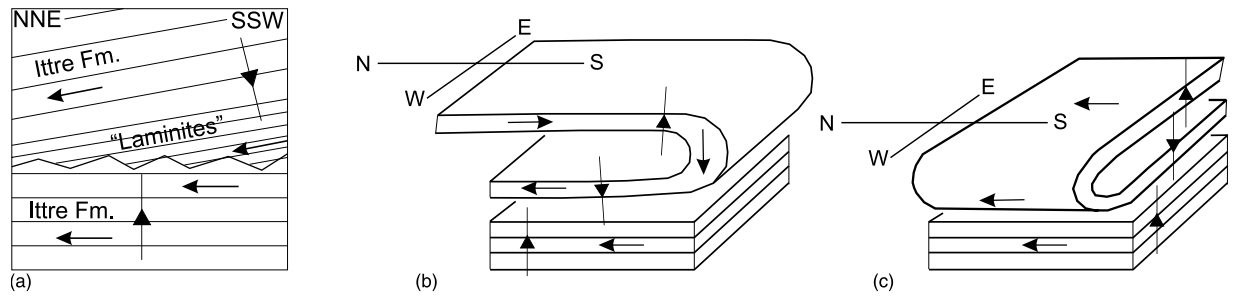

Fig. 11. Simplified geometry of the polarity reversal zone between the overturned slumped mass and the underlying relatively undisturbed turbidites of the Ittre Formation, showing palaeocurrent directions (arrows) deduced from depositional sedimentary features (a). Two possible ways to explain the observations: (b) slumping from the north or NE, from an area of southward or southwestward directed turbidity flows, with overturning around a NW-SE or east-west-axis; (c) slumping in an east-west or NW-SE direction, in an area of northward directed turbidity currents, with overturning around a north-south or NE-SW axis.

currents deduced from sediment dispersal (Klein 1964, 1966; Scott 1966). Following the ideas of Kneller et al. (1991), the observations in the southern rim of the Brabant Massif seem to suggest an elongated WNW-ESE-directed basin, with an eastdirected longitudinal turbidity current, generating flute casts, of which the radial spreading is limited by topography (e.g. basin margins). This can result in internal reflected flows, forming the ripples, and may provide an explanation for the differing trends between flute casts and ripples (cf. Louwye et al. 1992).

In an overturned position, depositional structures in the slumped beds indicate an apparent north-directed current, at low angles to the current direction in the upright underlying turbidites (5 on Fig. 10). Combined with the basin geometry put forward above, this leads to two possibilities (Figs 11 \& 12). If overturning occurred around an east-west- to NW-SEtrending axis, at a small angle to the basin slopes and to the axes of the small slump folds, the resulting SW-directed current within the turbidites (including the 'laminites') would imply reflected turbidity flow from the north or NE. These south-directed turbidites, thus far not encountered in other

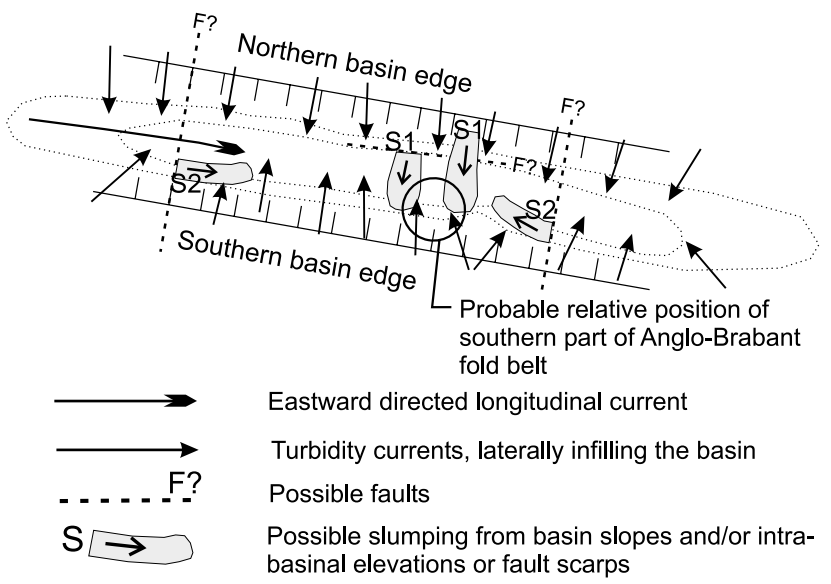

Fig. 12. Interpretation of the southern part of the Brabant Massif during Late Ordovician and Silurian times as belonging to the southern part of a NW-SE to east-west elongate basin with eastward directed longitudinal currents, being laterally infilled by turbidity currents. Because of the southern position in the basin, dominant turbidity current was directed northward. Large-scale middle Caradoc slumping either occurred from north (NE) to south (SW) (S1, cf. Fig. 11b) or in an east-west-direction (NW-SE) (S2, cf. Fig. 11c). Not to scale. localities along the southern rim of the Brabant Massif, may have been transported into the southern basin parts by means of a large slump. As noted by Woodcock (1979a) one of the characteristics of large slides and slumps is the allochthonous material they contain. These allochthonous deposits of outcrops B, B' and C, slumped on autochthonous turbidites of the Ittre Formation, were later covered by the autochthonous Bornival Formation. This is compatible with the difficulty of correlating the autochtonous turbidites of the Ittre Formation with the allochtonous, overturned, turbidites. Alternatively, if it is assumed that overturning took place along a north-south to NE-SW-directed axis, the east-west- to NW-SE-directed slump movement would necessitate a slope at high angles to the deduced basin trend. Although the advantage of this possibility is that turbidite palaeocurrents are still directed towards the north, this would imply that the axis of the large-scale slump fold is at high angles to the axes of the small slump folds.

\section{Probable cause of slumping}

The stability of a sedimentary deposit on a given slope, and hence the tendency to fail by slumping or sliding, depends largely on the shear-strength of the deposit and the rate of increase of this strength with depth of burial. These factors are controlled, in turn, by other properties such as grain size distribution, homogeneity, rate of accumulation, degree of consolidation and pore pressure conditions (Moore 1961).

The present eustatically drowned, wide shelves are essentially sediment traps which prevent a significant amount of the detrital material from reaching the continental slope. However, during glacial episodes, base-level drawdown results in rivers depositing their loads directly on the upper continental slopes, thereby favouring slumping (Moore 1961). Woodcock (1979a) considered this as a possible explanation for the high incidence and large sizes of slides on Pleistocene margins and suggested that large slides should be common during older glacial periods. Since the major Ordovician glaciation on Gondwana took place during Ashgill times (Dennison 1976; Destombes 1976; Hambrey 1985), the middle Caradoc slumping in the Brabant Massif cannot be related to this event.

Although slow even accumulation of sediments results in stable deposits, natural sediment traps will accelerate sedimentation locally and cause less stable deposits (Moore 1961). Although the older, turbiditic parts of the studied slump sheet may have a fairly low shear strength, favourable for slumping, the more slowly deposited, fine-grained, laminated sediments 
of outcrop $\mathrm{C}$ preclude rapid sedimentation or sediment overloading as a cause of slumping.

Basin floor faulting is often cited as a possible cause for slumping (Kuenen 1967; Corbett 1973). Earthquakes accompanying this faulting are likely to act as a trigger mechanism to initiate movement (Corbett 1973; Kastens 1984). However, slump folds are only one type of the many structures that can form in unconsolidated sediments under the influence of earthquakes. Depending on palaeoslope, lithology, water content, compaction, type, strength and duration of shock, a wide range of soft-sediment deformation structures, seismites, can form, ranging from isolated liquified zones to slides and slumps (Seilacher 1969; Vittori et al. 1991; Maltman 1994). Indeed, a variety of structures have been obtained by experiments simulating seismic shocks (e.g. Kuenen 1958; Moretti et al. 1999) and as a result numerous soft-sediment deformation structures have been attributed to earthquakes (e.g. Kuenen 1958; Seilacher 1969, 1984; Mutti et al. 1984; Kastens 1984; Spalletta \& Vai 1984; Roep \& Everts 1992; Pope et al. 1997). In ancient sediments, however, soft-sediment deformation structures can often be interpreted in various ways, necessitating additional and preferably independent lines of evidence in order to attribute the observed structures to earthquakes (cf. Seilacher 1984; Cita \& Ricci Lucchi 1984; Vittori et al. 1991; Roep \& Everts 1992).

The youngest beds of the overturned mass (outcrop C) contain numerous zones of small-scale soft-sediment deformation, both of biogenic and non-biogenic origin. The repetitive distribution of non-biogenic, small-scale soft-sediment deformation structures in outcrop $\mathrm{C}$, in zones of variable thickness, separated by less deformed or undeformed zones, suggests that they are not the result of a single event, but reflect recurring events. We suggest that these soft-sediment deformation intervals were generated by earthquakes and that one, probably larger, earthquake triggered the large-scale slumping. This is a reasonable scenario, given the Late Ordovician palaeogeographic position of the Anglo-Brabant fold belt, as a part of eastern Avalonia approaching Baltica, and the presence of early Ashgill calcalcaline subduction-related magmatism in the Brabant Massif (André et al. 1986; Van Grootel et al. 1997).

A possible candidate for seismically triggering this large-scale slumping is the Asquempont fault (Fig. 2), which forms the limit between the Lower to lower Middle Cambrian and the Lower Ordovician and is considered to be one of the most important structural features of the Brabant Massif (Legrand 1967; Sintubin 1999).

\section{Conclusions}

A comparison of cleavage/fold relationships and stratigraphic polarity shows that a mass of minimum $200 \mathrm{~m}$ thickness of fine-grained middle Caradoc turbidites in the core of a large tectonic synform was overturned prior to the Early to early Mid-Devonian single-phase tectonic deformation. This overturning is attributed to large-scale slumping.

Palaeocurrent directions derived from depositional and erosional sedimentary features in the turbidite deposits suggest that during the Late Ordovician and Silurian the southern Brabant Massif was part of a NW-SE- to east-west-trending basin. The orientation of the small slump folds is compatible with this basin geometry. Although the exact origin and sense of movement of the large-scale slumped mass remains unknown, a comparison of palaeocurrent directions and other data can be used to reduce the number of possibilities.

The most likely trigger mechanism for this large-scale slumping is earthquake activity during the middle Caradoc, when eastern Avalonia was approaching Baltica.

Observing the apparent discrepancy in size between recent and ancient slides, the former being several orders of magnitude larger than the latter, Woodcock (1979a) put forward the question why so few large ancient slides and slumps have been reported. The observations presented in this paper may explain why. The slump sheet, having a minimum thickness of $200 \mathrm{~m}$, only contains several small slump folds and intraformational breccias, taking up less than $5 \%$ of the exposed thickness of the slump sheet. Therefore, if the beds were not overturned, the small slump folds would have been interpreted as localized slump folds in an overall 'stable' sedimentary sequence. Thus, one probable reason why so few large ancient slides have been reported is their high internal cohesion, resulting in very little internal deformation which makes them very difficult to recognize, especially in poorly exposed areas. Consequently, especially when considering the low angles of slopes on which earthquake-induced sediment failure may occur (Field et al. 1982; Bugge et al. 1987), large ancient slides and slumps may be more common than suggested by the geological literature.

The authors are grateful to J. Samuelsson, A. R. Prave and N. H. Woodcock for fruitful discussions and constructive remarks. N. H. Woodcock, A. Maltman, R. J. Lisle, M. Houchen, A. R. Prave and M. Brown are kindly acknowledged for critically reading the manuscript. T. N. Debacker is research assistant, M. Sintubin is postdoctoral fellow and J. Verniers is research director of the Fund for Scientific Research-Flanders (F.W.O.-Vlaanderen, Belgium). This work forms part of the Research Project No. G.0084.97 of the F.W.O.-Vlaanderen.

\section{References}

André, L., Hertogen, J. \& Deutsch, S. 1986. Ordovician-Silurian magmatic provinces in Belgium and the Caledonian orogeny in middle Europe. Geology, 14, 879-882.

BLEwEtT, R.S. 1991. Slump folds and early structures, northeastern Newfoundland Appalachians: re-examined. Journal of Geology, 99, $547-557$.

Bouma, A.H. 1962. Sedimentology of some flysch deposits. Elsevier, Amsterdam. Bugge, T., Befring, S., Belderson, R.H., Eidvin, T., Jansen, E., Kenyon, N.H., Holtedahl, H. \& SeJrup, H.P. 1987. A giant three-stage submarine slide off Norway. Geo-Marine Letters, 7, 191-198.

Cita, M.B. \& Ricci Lucchi, F. (EDS) 1984. Seismicity and sedimentation. Marine Geology, 55, 1-161.

CorbetT, K.D. 1973. Open-cast slump sheets and their relationship to sandstone beds in an Upper Cambrian flysch sequence, Tasmania. Journal of Sedimentary Petrology, 43, 147-159.

Corin, F. 1963. Sur les roches éruptives de la tranchée d'Hasquempont, canal de Charleroi. Bulletin de la Société belge de Géologie, de Paléontologie et d'Hydrologie, 72, 55-60.

Cummins, W.A. 1957. The Denbigh Grits; Wenlock greywackes in Wales. Geological Magazine, 94, 433-451.

DEBACKER, T.N. 1999. Folds trending at various angles to the transport direction in the Marcq area, Brabant Massif, Belgium. Geologica Belgica, 2, $159-172$.

Debacker, T.N., Sintubin, M. \& Verniers, J. 1999. Cleavage/fold relationships in the Silurian metapelites, southeastern Anglo-Brabant fold belt (Ronquières, Belgium). Geologie en Mijnbouw, 78, 47-56.

Dennison, J.M. 1976. Appalachian Queenston Delta related to eustatic sea-level drop accompanying Late Ordovician glaciation centred in Africa. In: Bassett, M.G. (ed.) The Ordovician system: proceedings of a Palaeontological Association symposium. Birmingham, September 1974, 107-120. 
Destombes, J. 1976. The Ordovician of the Moroccan Anti-Atlas. In: BassetT, M.G. (ed.) The Ordovician system: proceedings of a Palaeontological Association symposium. (Birmingham, September 1974, 411-413.

De Vos, W., Verniers, J., Herbosch, A. \& Vanguestaine, M. 1993. A new geological map of the Brabant Massif, Belgium. Geological Magazine, 130, 605-611.

Dewey, J.F. 1962. The provenance and emplacement of upper Arenigian turbidites in Co. Mayo, Eire. Geological Magazine, 99, 238-252.

Elliott, C.G. \& Williams, P.F. 1988. Sediment slump structures: a review of diagnostic criteria and application to an example from Newfoundland. Journal of Structural Geology, 10, 171-182.

Field, M.E., Gardner, J.V., Jennings, A.E. \& Edwards, B.D. 1982 Earthquake induced sediment failures on a 0.25 degrees slope, Klamath River delta, California. Geology, 10, 542-546.

Giese, U., Katzung, G., Walter, R. \& Weber, J. 1997. The Caledonian deformation of the Brabant Massif and the Early Palaeozoic in northeast Germany: compared. Geological Magazine, 134, 637-652.

Gorsline, D.S. \& EMERY, K.O. 1959. Turbidity-current deposits in San Pedro and Santa Monica Basins off southern California. Geological Society of America Bulletin, 70, 279-290.

Hambrey, M.J. 1985. The Late Ordovician-Early Silurian glacial period Palaeogeography, Palaeoclimatology, Palaeoecology, 51, 273-289.

HANSEN, E. 1965. Methods of deducing slip-line orientations from the geometry of folds. Year Book of the Carnegy Institute Washington, 65, 387-405.

HelwiG, J. 1970. Slump folds and early structures, northeastern Newfoundland Appalachians. Journal of Geology, 78, 172-187.

Herbosch, A., Vanguestaine, M., Degardin, J.M., Dejonghe, L., Fagel, N. \& SERVAIS, T. 1991. Etude lithostratigraphique, biostratigraphique et sédimentologique du sondage de Lessines (bord méridional du Massif du Brabant, Belgique). Annales de la Société géologique de la Belgique, 114, 195-212.

JoNES, O.T. 1939. The geology of the Colwyn Bay district: a study of submarine slumping during the Salopian Period. Quarterly Journal of the Geological Society of London, 95, 335-382.

Kastens, K.A. 1984. Earthquakes as a triggering mechanism for debris flows and turbidites on the Calabrian Ridge. Marine Geology, 55, 13-33.

KeLLING, G. 1962. The petrology and sedimentation of Upper Ordovician rocks in the Rhinns of Galloway, southwest Scotland. Transactions of the Royal Society of Edinburgh, 65, 107-137.

Kelling, G. 1964. The turbidite concept in Britain. In: Bouma, A.H. \& Brouwer, A. (eds) Turbidites: Developments in sedimentology. Elsevier, Amsterdam, 75-92.

Kelling, G. \& Williams, B.P.J. 1966. Deformation structures of sedimentary origin in the Lower Limestone Shales (basal Carboniferous) of South Pembrokeshire, Wales. Journal of Sedimentary Petrology, 36, 927-939.

KLeIN, G. DeV. 1964. Sandstone petrogenesis of the Stanley-Jackfork boundary (Mississippian), Ouachita fold belt, Arkansas and Oklahoma (abstract). Geological Society of America Special Paper, 76, 92.

KLEIN, G. DeV. 1966. Dispersal and petrology of sandstones of Stanley-Jackfork boundary, Ouachita fold belt, Arkansas and Oklahoma. Bulletin of the American Association of Petroleum Geologists, 50, 308-326.

Kneller, B., Edwards, D., McCaffrey, W. \& Moore, R. 1991. Oblique reflection of turbidity currents. Geology, 19, 250-252.

KuENEN, P.H. 1949. Slumping in the Carboniferous rocks of Pembrokeshire. Quarterly Journal of the Geological Society of London, 104, 365-380.

Kuenen, P.H. 1957. Longitudinal filling of oblong sedimentary basins. Verhandelingen van het Koninklijk Nederlands Geologisch-Mijnbouwkundig Genootschap, Geologische Serie, 18, 189-195.

KuENEN, P.H. 1958. Experiments in geology. Glasgow Geological Society Transactions, 23, 1-28.

KuENEn, P.H. 1967. Emplacement of flysch-type sand beds. Sedimentology, 9 , 203-243.

LAJOIE, J. 1972. Slump fold axis orientations: an indication of paleoslope? Journal of Sedimentary Petrology, 42, 584-586.

Legrand, R. 1967. Ronquières, documents géologiques. Mémoires pour servir à l'explication des Cartes géologiques et minières de la Belgique, 6 .

Legrand, R. 1968. Le Massif du Brabant. Mémoires pour servir à l'explication des Cartes géologiques et minières de la Belgique, 9.

Legros, B. 1991. Etude structurale du Cambro-Ordovicien de la vallée de la Sennette (Massif du Brabant)-Belgique. MSc thesis. Université Catholique de Louvain.

Louwye, S., Van Grootel, G. \& Verniers, J. 1992. The stratigraphy of the type locality of the ?late Wenlock/early Ludlow Mont Godart Formation and the early Ludlow Ronquières Formation, Brabant Massif, Belgium. Annales de la Société géologique de la Belgique, 115, 307-331.
Maltman, A.J. 1981. Primary bedding-parallel fabrics in structural geology. Journal of the Geological Society, London, 138, 475-483.

MaLtman, A.J. 1994. The geological deformation of sediments. Chapman \& Hall, London.

Martin, F. \& Rickards, B. 1979. Acritarches, chitinozoaires et graptolithes ordoviciens et siluriens de la vallée de la Sennette (Massif du Brabant, Belgique). Annales de la Société géologique de la Belgique, 102, 189-197.

Moore, D.G. 1961. Submarine slumps. Journal of Sedimentary Petrology, 31, 343-357.

Moretti, M., Alfaro, P., Caselles, O. \& Canas, J.A. 1999. Modelling seismites with a digital shaking table. Tectonophysics, 304, 369-383.

Mutti, E., Ricci Lucchi, F., Seguret, M. \& Zanzucchi, G. 1984. Seismoturbidites: a new group of resedimented deposits. Marine Geology, 55, 103-116.

Pettijohn, F.J., Potter, P.E. \& Siever, R. 1987. Sand and Sandstone (second edition). Springer, Berlin.

Pope, M.C., Read, J.F., Bambach, R. \& Hofmann, H.J. 1997. Late Middle to late Ordovician seismites of Kentucky, southwest Ohio and Virginia: Sedimentary recorders of earthquakes in the Appalachian basin. Geological Society of America Bulletin, 109, 489-503.

Potter, P.E. \& PetTijohn, F.J. 1977. Paleocurrents and Basin Analysis (revised and up-dated 2nd edn). Springer, Berlin.

RicCI LuCCHI, F. 1978. Turbidite dispersal in a Miocene deep-sea plain: the Marnoso-arenacea of the northern Apennines. Geologie en Mijnbouw, 57, $559-576$.

Roep, T.B. \& Everts, A.J. 1992. Pillow-beds: a new type of seismites? An example from an Oligocene turbidite fan complex, Alicante, Spain. Sedimentology, 39, 711-724.

RUPKE, N.A. 1976. Large-scale slumping in a flysch basin, Southwestern Pyrenees. Journal of the Geological Society, London, 132, 121-130.

ScotT, K.M. 1966. Sedimentology and dispersal pattern of a Cretaceous flysch sequence, Patagonian Andes, southern Chile. Bulletin of the American Association of Petroleum Geologists, 50, 72-107.

Seilacher, A. 1969. Fault-graded beds interpreted as seismites. Sedimentology, 13, 155-159.

SeILACher, A. 1984. Sedimentary structures tentatively attributed to seismic events. Marine Geology, 55, 1-12.

Servais, T. 1991. Discovery of turbiditical levels in the Late Ordovician of the Sennette valley (Brabant Massif, Belgium). Annales de la Société géologique de la Belgique, 114, 247-251.

Sintubin, M. 1999. Arcuate fold and cleavage patterns in the southeastern part of the Anglo-Brabant Fold Belt (Belgium): tectonic implications. Tectonophysics, 309, 81-97.

SMith, R.D.A. \& ANKETELL, J.M. 1992. Welsh Basin "contourites' reinterpreted as fine-grained turbidites: the Grogal Sandstones. Geological Magazine, 129, 609-614

Soper, N.J., WebB, B.C. \& Woodcock, N.H. 1987. Late Caledonian (Acadian) transpression in north-west England: timing, geometry and geotectonic significance. Proceedings of the Yorkshire Geological Society, 46, 175-192.

Spalletta, C. \& VAI, G.B. 1984. Upper Devonian intraclast parabreccias interpreted as seismites. Marine Geology, 55, 133-144.

Stow, D.A.V. \& LovelL, J.P.B. 1979. Contourites: Their recognition in modern and ancient sediments. Earth-Science Reviews, 14, 251-291.

Van Grootel, G., Samuelsson, J. \& Verniers, J. 1998. Micropaleontologie en biostratigrafie van het Ordovicium, . Unpublished final report of Project NAT/96-3.3.

Van Grootel, G., Verniers, J., Geerkens, B., Laduron, D., Verhaeren, M., Hertogen, J. \& De Vos, W. 1997. Timing of subsidence-related magmatism, foreland basin development, metamorphism and inversion in the Anglo-Brabant fold belt. Geological Magazine, 134, 607-616.

Verniers, J. 1983. The Silurian of the Mehaigne area (Brabant Massif, Belgium), lithostratigraphy and features of the sedimentary basin. Professional Paper of the Geological Survey of Belgium, 203, 1-117.

Verniers, J. \& Van Grootel, G. 1991. Review of the Silurian in the Brabant Massif, Belgium. In: André, L., Herbosch, A., Vanguestaine, M. \& Verniers, J. (eds) Proceedings of the international meeting on the Caledonides of the Midlands and the Brabant Massif, Brussels, 1989. Annales de la Société Géologique de Belgique, 114, 163-193.

Verniers, J., Herbosch, A., Vanguestaine, M., Geukens, F., Delcambre, B., Pingot, J.L., Bellanger, I., Hennebert, I., Debacker, T., Sintubin, M. \& De Vos, W. 2001. The Lower Palaeozoic formations in Belgium. Geologica Belgica, in press.

Vittori, E., Sylos Labini, S. \& Serva, L. 1991. Palaeoseismology: review of the state-of-the-art. Tectonophysics, 193, 9-32. 
Williams, P.F., Collins, A.R. \& Wiltshire, R.G. 1969. Cleavage and penecontemporaneous deformation structures in sedimentary rocks. Journal of Geology, 77, 415-425

Woodcock, N.H. 1976. Structural style in slump sheets: Ludlow Series, Powys, Wales. Journal of the Geological Society, London, 132, 399-415.
Woodcock, N.H. 1979a. Sizes of submarine slides and their significance. Journal of Structural Geology, 1, 137-142.

WoODCOCK, N.H. 1979b. The use of slump structures as palaeoslope orientation estimators. Sedimentology, 26, 83-99.

Received 10 July 2000; revised typescript accepted 2 November 2000

Scientific editing by Alex Maltman. 